\title{
Hashimoto Thyroiditis in Childhood - Review of the Epidemiology, Genetic Susceptibility and Clinical Aspects of the Disease
}

\author{
Nikolina Zdraveska and Mirjana Kocova \\ University Children's Hospital, Faculty of Medicine, Ss Cyril and Methodius University Skopje, Skopje, Republic of Macedonia
}

Citation: Zdraveska N, Kocova M. Hashimoto Thyroiditis in Childhood - Review of the Epidemiology, Genetic Susceptibility and Clinical Aspects of the Disease. Maced J Med Sci. 2012 Oct 15: 5(3):336-345. http:/dx. doi.org/10.3889/ MJMS.1857-5773.2012.0247.

Key words: Hashimoto thyroiditis; childhood; epidemiology; genetic susceptibility; review.

Correspondence: Prof. Mirjana Kocova, PhD, MD. Institution: University Children's Hospital, Vodnjanska 17, 1000 Skopje, Republic of Macedonia Phone: + 38923111713 Fax: + 389 2322027 . E-mail: mirjanakocova@yaxoo.com

Received: 05-May-2012; Revised: 19-Jun-2012 Accepted: 30-Jun-2012; Online first: 03-Oct-2012

Copyright: $\odot 2012$ Zdraveska N. This is an openaccess article distributed under the terms of the Creative Commons Attribution License, which permits unrestricted use distribution, and reproductioninany medium, provic

Competing Interests: The author have declared that no competing interests exist.

\begin{abstract}
Chronic autoimmune thyroiditis or Hashimoto's thyroiditis $(\mathrm{HT})$ is the most common cause of thyroid disease in children and adolescents. It is also the most common cause of acquired hypothyroidism with or without goiter. The incidence of autoimmune thyroiditis has increased dramatically over the past few decades, affecting up to $5 \%$ of the general population in iodine sufficient areas. HT is caused by the complex interplay of genetic, environmental, and endogenous factors. Significant progress has been made in identifying and characterizing the genes involved in pathogenesis of the disease.
\end{abstract}

The aim of this review is to analyze current opinions and options regarding the etiology, genetic contribution to the pathogenesis, evaluation, diagnosis, treatment, and prognosis of the $\mathrm{HT}$ in children.

\section{Introduction}

Chronic autoimmune thyroiditis (chronic lymphocytic thyroiditis or Hashimoto's thyroiditis) is the most common endocrine disorder in childhood and adolescence. Also it is the most common cause of acquired hypothyroidism in children. Thyroid hormones have critical impact on early brain development, somatic growth, bone maturation; they play a role in synthesis of more than 100 proteins that constantly regulate each and every function in the body. Optimal thyroid hormone quantity is important because a prolonged hypothyroid state before starting treatment in children may result in incomplete catch-up growth [1], obesity [2] and precocious pseudo-puberty [3].

Hashimoto thyroiditis (HT) results from complex cellular and humoral immune reactions to thyroid antigens 
that occur in genetically predisposed individuals presumably triggered by some environmental factor.

Advances in molecular methods in the past years enabled significant progress in our understanding of the immunogenetic mechanisms leading to thyroid autoimmunity. Genetic analyses undertaken in the last decade have revealed a completely new picture of autoimmune thyroid disease pathogenesis and raised awareness of heterogeneity among individuals and populations.

This review will summarize the current studies regarding the etiology, genetic susceptibility, pathogenesis, evaluation, diagnosis, treatment and prognosis of Hashimoto thyroiditis in children.

\section{Methods}

Electronic bases: PubMed, Medline, Cochrane Database of Systematic Reviews were searched for relevant articles using the key words: autoimmune thyroiditis, Hashimoto thyroiditis, chronic lymphocitytic thyroiditis, children, goiter, and hypothyroidism. The main papers analyzed were original studies, review articles and clinical practice guidelines. Reference lists of the relevant articles were scanned for additional studies.

Studies were selected according to the following criteria: 1) original studies reporting the epidemiological and clinical characteristics of the disease, 2) original data reporting clinical course and long term outcome; 3) recent review articles analyzing the genes involved in the thyroid autoimmunity.

Studies published in English and in other languages were included.

Textbooks of pediatrics and pediatric endocrinology available in print or online version that contained relevant updated data were also used for this review.

\section{Discussion}

\section{Definition}

Autoimmune thyroiditis or chronic lymphocytic thyroiditis is defined as evidence of "intrathyroidal lymphocytic infiltration" with or without follicular damage.

Two types of autoimmune thyroiditis are causes of persistent hypothyroidism: Hashimoto's disease (goitrous form) and atrophic thyroiditis (nongoitrous form). Both are characterized by circulating thyroid autoantibodies and varying degrees of thyroid dysfunction, the only difference being the presence or absence of goiter.

In 1912, Hashimoto first described chronic lymphocytic thyroiditis in women with asymptomatic goiter. After surgical removal of the gland, the author classified it as struma lymphomatosa, apparent transformation of thyroid into lymphoid tissue.

Later on, in 1938, diagnosis was made in children presenting goiter with lymphocytic infiltrate. Until 1956, when antibodies were detected, it was considered a rare disease in pediatrics, but since then incidence is rapidly increasing.

\section{Epidemiology}

Autoimmune thyroid disease (ATD) is the most common organ-specific autoimmune condition, affecting up to $5 \%$ of the general population [4]. Although the prevalence peaks in adulthood; it is also the most common etiology of acquired thyroid disease in children and adolescents in iodine sufficient areas.

The frequency of HT has been reported to be between $0.3 \%$ and $9.6 \%$ in children and adolescent age groups $[5,6]$.

The prevalence reported in the studies varies mainly depending on the diagnostic criteria, ethnicity, iodine status and age or sex of the population studied.

Autoimmune thyroiditis is being increasingly identified in the young population due to various reasons, such as increasing awareness, availability of better antibody assays, and skilled cytopathologists to perform and interpret fine needle aspirations. In recent years several studies assessing clinical and epidemiological characteristics of children and adolescents with HT have been published in the literature (Table 1) [7-12].

The childhood prevalence peaks in early to midpuberty, and in all of the studies female predominance is reported up to $10-15: 1$. Presentation is rare under the age of 3 years, but cases have been reported even in infancy [13].

An increased frequency of ATDs is reported in Turner syndrome and in other nondisjunctional chromosomal disorders such as Down and Klinefelter syndromes. 
Table 1: Epidemiological characteristics of children and adolescents with HT reported in recent published studies.

\begin{tabular}{|c|c|c|c|c|c|c|}
\hline $\begin{array}{l}\text { Author - year } \\
\text { (ref) }\end{array}$ & $\begin{array}{l}\text { Number } \\
\text { of } \\
\text { patients }\end{array}$ & $\begin{array}{l}\text { Reason for } \\
\text { referral }\end{array}$ & $\begin{array}{c}\begin{array}{c}\text { Age } \\
\text { (years) }\end{array}\end{array}$ & $\begin{array}{c}\text { Female } \\
(\%)\end{array}$ & $\begin{array}{c}\text { Euthyroid \% } \\
\text { Subclinically } \\
\text { hypothyroid \% } \\
\text { Hypothyroid \% }\end{array}$ & $\begin{array}{c}\text { Goiter } \\
(\%)\end{array}$ \\
\hline $\begin{array}{l}\text { Svensson et al } \\
2006(7)\end{array}$ & 90 & Not specified & $\begin{array}{l}\text { female: } 26 \\
\text { male: } 14.0\end{array}$ & 81 & $\begin{array}{l}39 \\
47 \\
14\end{array}$ & 68 \\
\hline $\begin{array}{l}\text { Demirbilek et al } \\
2007 \text { (8) }\end{array}$ & 162 & $\begin{array}{l}\text { Mostly goiter } \\
\text { or signn of } \\
\text { hypothyroidism }\end{array}$ & $\begin{array}{l}11.4 \pm 2.97 \\
(m e a n \pm S D)\end{array}$ & 86.4 & $\begin{array}{l}43.2 \\
24.1 \\
21.0\end{array}$ & 84.4 \\
\hline $\begin{array}{l}\text { Gopalakrishnan } \\
\text { et al } 2008 \text { (9) }\end{array}$ & 98 & Goiter & $\begin{array}{l}13.2 \pm 2.6 \\
\text { (mean } \pm \text { SD) }\end{array}$ & 80.9 & $\begin{array}{l}24.5 \\
32.6 \\
42.9\end{array}$ & 100 \\
\hline $\begin{array}{l}\text { Corrias et al } \\
2008 \text { (10) }\end{array}$ & 365 & $\begin{array}{l}\text { Mostly goiter } \\
\text { or signs of } \\
\text { hypothyroidism }\end{array}$ & $\begin{array}{l}3.6-17.0 \\
\text { (Range) }\end{array}$ & 84 & $\begin{array}{l}53.4 \\
1 \\
43.6\end{array}$ & 79 \\
\hline $\begin{array}{l}\text { De Vries et al } \\
2009 \text { (11) }\end{array}$ & 114 & $\begin{array}{l}\text { Mostly goiter } \\
\text { or signs of } \\
\text { hypothyroidism }\end{array}$ & $\begin{array}{l}11.8 \pm 3.6 \\
\text { (mean } \pm S D)\end{array}$ & 80.7 & $\begin{array}{l}21 \\
42 \\
37\end{array}$ & 77.2 \\
\hline $\begin{array}{l}\text { Skarpa et al } \\
2011 \text { (12) }\end{array}$ & 228 & $\begin{array}{l}\text { Mostly } \\
\text { asymptomatic }\end{array}$ & $\begin{array}{l}10.2 \pm 2.5 \\
(\text { mean } \pm S D)\end{array}$ & 83.8 & $\begin{array}{r}57.0 \\
32.9 \\
8.3\end{array}$ & 28 \\
\hline
\end{tabular}

The theory that maternal autoimmunity may lead to the preferential survival of a fetus with chromosomal aneuploidy remains unproven [14]. The most prevalent autoimmune disorder in Turner syndrome appears to be chronic autoimmune thyroiditis, with a reported thyroid autoantibody incidence in $30-50 \%$ of patients. Hypothyroidism of autoimmune origin is so common in Turner syndrome that almost every second Turner syndrome woman will probably develop hypothyroidism, and it will increase with age $[15,16]$.

Clinically similar and antibodies negative hypothyroidism frequently described in obese children should be distinguished from $\mathrm{HT}$, although classical HT might appear in this population [17].

\section{Etiology}

Autoimmune thyroid disorders result from a complex interplay of genetic, environmental, and endogenous factors $[18,19]$.

Early evidence of the genetic component of ATD was supported by several familial and twins studies. Early twins studies estimated the concordance rate for disease in identical (monozygotic twins to be $50-70 \%$, and $3-25 \%$ for non-identical (dizygotic) twins for autoimmune hypothyroidism [20]. Later studies reported concordance rate of $35 \%$ in monozygotic twins. As the concordance rates for the disease fall below $100 \%$ in monozygotic twins, that share the identical DNA, environmental (nongenetic) factors must play a role in the development of autoimmune thyroiditis. In one study, the $\lambda s$ (ratio of the prevalence in siblings of affected individuals to the prevalence in the general population) was 16.9 ( $>5$ being significant), indicating an important role of genetic susceptibility [21].
This genetic susceptibility shows necessity of familial regular screening.

Advances in genetic methods in the past 15 years enabled significant progress in the identification of complex disease genes. A number of review articles in recent years have been published describing the genetic background of the autoimmune thyroid disease.

Candidate gene analysis, whole-genome linkage screening, genome-wide association studies, and wholegenome sequencing are the major technologies that have advanced this field, leading to the identification of at least seven genes whose variants have been associated with AITD [22].

Some of these susceptibility genes are specific to either Graves disease (GD) or Hashimoto thyroiditis, while others showed susceptibility to both diseases.

The identified ATDs susceptibility genes can be divided into two broad groups: (1) immune modulating genes, and (2) thyroid specific genes.

The first group immunomodulatory genes include: HLA-DR, CD40, cytotoxic T lymphocyteassociated factor (CTLA-4), and protein tyrosine phosphatase 22 (PTPN22), while the second group includes the thyroglobulin $(\mathrm{Tg})$ and $\mathrm{TSH}$ receptor genes.

The first identified ATD susceptibility gene locus was the human leukocyte antigen DR (HLA-DR) gene locus. Several studies showed association of Hashimoto thyroiditis with HLA-DR3 and HLA-DR4 antigens [2325].

Recently, Zeitlin etal. investigated DRB1-DQB1DQA1 haplotypes in the largest UK Caucasian Hashimoto thyroiditis case control cohort to date comprising 640 Hashimoto thyroiditis patients and 621 controls. A strong association between HT and DR4 haplotype (DRB1*04DQB1*03-QA1*03) was detected, and protective effects were detected for DR13 haplotype (DRB1*13-DQB1*06DQA1*01) and DR7 [27].

CD40 is expressed primarily on B-cells and other antigen presenting cells (APC), and plays a fundamental role in B-cell activation and antibody secretion and generation of memory cells. Since CD40 is a major APC and B-cell costimulatory molecule, it seems plausible that $\mathrm{CD} 40$ will play a role in the genetic susceptibility to other autoimmune diseases. Tomer et al. have demonstrated that the CC genotype at the 5' untranslated region of CD40 is linked and associated with Graves' disease [27]. 
Indeed, recent data have shown that CD40 was associated and/or linked with high IgE levels in asthma [28], rheumatoid arthritis [29], systemic lupus erythematosus [30], and multiple sclerosis [31].

CTLA-4 is a transmembrane protein of the immunoglobulin (Ig) superfamily, an important molecule that acts as a major negative regulator of $\mathrm{T}$-cell activation by binding to the B7 molecules present on antigenpresenting cells and preventing the second signal necessary for T-cell activation. CTLA-4 gene polymorphism is established as an autoimmunity gene shown to be linked and/or associated with various autoimmune conditions. These include both GD and HT, as well as the production of thyroid antibodies alone without clinical disease [32].

Protein tyrosine phosphatase22 (PTPN22) encodes a protein, lymphoid tyrosine phosphatase (LYP), which is a potent inhibitor of the T-cell receptor signaling pathway. A tryptophan for arginine substitution at codon 620 of the LYP molecule has been associated with both Graves' disease and Hashimoto thyroiditis in some but not all ethnic populations [33-35].

In a recent study performed in Japanese population, a novel protective effect of a haplotype containing five SNPs in this gene was observed for HT [36].

Antibodies against thyroid peroxidase are one of the most specific features of $\mathrm{HT}$. Therefore, the thyroid peroxidase gene was expected to be a putative candidate responsible for susceptibility to HT. However, casecontrol studies showed lack of association between the thyroid peroxidase gene polymorphisms and ATD. These data suggest that the thyroid peroxidase gene does not play an important role in predisposition to HT [37, 38].

The thyroglobulin ( $\mathrm{Tg}$ ) is the major thyroid autoantigen in autoimmune thyroid disease, evidenced by the fact that $\mathrm{HT}$ is characterized by antithyroglobulin antibodies detected in almost all of the patients. Both linkage and association studies further localized these polymorphisms to two new Tg microsatellites in introns 10 and 27.Detailed sequence analysis of the Tg gene demonstrated significant associations between specific Tg single nucleotide polymorphisms (SPNs) and both Graves' disease and HT in three different data sets [36, 39].

Within the other thyroid-specific gene, the TSHR gene was mapped on chromosome 14q. A number of different SNPs of the TSH receptor have been associated with autoimmune thyroid disease [40].

One of the many unexpected findings of these genetic studies was that most of the identified genes have very minor effects; most of them with a low odd ratios of $<1.5$ [41].

It is usually supposed that a strong genetic effect on disease is related to the inheritance of many genes with small effect. Two alternative mechanisms have been proposed for the very low odd ratios involvement for most ATDs genes: subset effect and gene-gene interactions.

According to the "gene-gene interaction" model, two genes with weak effects interact, biologically resulting in a combined odd ratio that is significantly higher than the one expected with an additive effect alone.

According to the "subset" or genetic heterogeneity model each of the genetic variants identified has a large effect resulting in a high odd ratio in a subset of the ATD patients studied. However, when these variants are tested in the entire population of ATD patients, their effects are diluted, resulting in much smaller odd ratios [42].

Genetic factors predominate, accounting for approximately $80 \%$ of the likelihood of developing ATDs,whereas at least $20 \%$ is due to non-genetic factors. Several environmental and non-genetic triggers have been implicated in the etiology of HT including nutrition, stress, infection, trauma, medications and irradiation. lodine is one of the most important precipitants of thyroid dysfunction. Although essential for normal thyroid function, excess iodine supplementation can be associated with the onset of thyroid autoimmunity. Several studies have demonstrated increased incidence of autoimmune thyroiditis in regions where iodine consumption is high compared to regions with low consumption [5, 433, 44].

Selenium (Se) may play an essential role in thyroid hormone synthesis: two enzymes involved in the thyroid hormone pathway are selenoproteins, namely deiodinases and glutathione peroxidase. Adequate Se nutrition supports efficient thyroid hormone synthesis and metabolism and protects the thyroid gland from damage from excessive iodine exposure.

Derumeaux et al. discovered an inverse association between Se status and thyroid volume and echostructure in French adults and concluded that Se may protect against ATDs [45]. Duntas et al. found 
beneficial effects when treating patients with autoimmune thyroiditis with selenomethionine for 6 months due to its ability to reduce anti-TPO antibodies [46].

The most common medications that may play a role in the development of HT are: amiodarone, interferon$\alpha$, interleukin-2, lithium, and antiretroviral therapy.

Several infections have been implicated in the pathogenesis of $\mathrm{HT}$ including Helicobacter pylori, Borrelia burgdorferi, Yersinia enterocolitica, Coxsackie virus, and retroviruses. The strongest association of Hashimoto's thyroiditis with an infectious agent is with Hepatitis C virus [47].

Irradiation of the thyroid gland, as in therapy for malignancies, may predispose to autoimmunity due to exposure of thyroidal antigens to the immune system. Many environmental pollutants, such as polyaromatic hydrocarbons, perfluorinated chemicals, phthalates, and bisphenol A, have been shown to be toxic to thyroid cells and promote the onset of HT [48]. These chemicals are widely used in various industrial and consumer products.

\section{Pathogenesis}

In an initial stage of the pathogenesis, antigenpresenting cells (APC), mostly dendritic cell and macrophage infiltrate the thyroid gland. The infiltration can be induced by some envinromental triggering factor which causes insult on thyrocytes and release of thyroidspecific proteins.

These proteins serve as a source of self-antigenic peptides that are presented on the cell surface of APC after processing. A central phase of HT is characterized by the recognition of presented autoantigens by the lymphocytes, followed by an apparent uncontrolled production of autoreactive CD4+ T cells, CD8+ cytotoxic $T$ cells and autoantibodies. In a final, destructive stage of Hashimoto's thyroiditis, the autoreactive T cells in large numbers infiltrate thyroid parenchyma, causing massive depletion of thyrocytes via antibody-dependent, cytokine mediated and apoptotic mechanisms.

Thyroglobulin ( $\mathrm{Tg}$ ) is one of the major autoantigens in thyroid autoimmunity and serologic studies have shown that there are at least 40 antigenic epitopes on human $\mathrm{Tg}$. Tg-antibodies are detected in almost all patients with ATD. Anti-thyroglobulin antibodies were also reported in up to $27 \%$ of normal individuals $[49,50]$.

Thyroid peroxidase (TPO) is another significant autoantigen in the thyroid in patients with HT. This enzyme catalyses the oxidation of iodine to an iodinating species that forms iodotyrosines in a Tg molecule and subsequently iodotyronines. TPO antibodies are heterogeneous and so far, around 180 human TPO antibodies have been cloned and sequenced [51].

Autoantibodies against other thyroid-specific antigens such as thyrotropin receptor and sodium iodide symporter were also found in serum of HT patients. However, these antibodies occur rarely and do not contribute to the diagnosis of HT. Histologically, goitrous $\mathrm{HT}$ is characterized by a diffuse lymphocytic infiltration with occasional germinal centers. Thyroid follicles may be reduced in size and contain sparse colloid. Individual thyroid cells are often enlarged, with oxyphilic cytoplasm (usually defined Hurthle cells). In contrast, the gland of atrophic AT is small, with lymphocytic infiltration and fibrous replacement of the parenchyma [52].

Hence, with a loss of functional thyroid tissue caused by these processes, hormonal depletion leads to hypothyroidism.

\section{Clinical manifestations}

The most common clinical manifestations of Hashimoto thyroiditis are goiter and hypothyroidism. Clinical manifestations at the time of presentation can vary from euthyroidism to different degrees of thyroid dysfunction, either overt or subclinical forms of hypothyroidism and very rarely hyperthyroidism.

Asymptomatic enlargement of the thyroid gland is a common presenting complaint, especially in older children and adolescents. The goiter may appear insidiously and may be small or large. In most patients, the thyroid is diffusely enlarged, firm, and nontender. In about $30 \%$ of patients, the gland is lobular and may seem to be nodular [53].

Occasionally, complaint of "sore" neck in extended position might be reported by the patient. As the disease progresses, subclinical and then clinical hypothyroidism appears. The clinical manifestations due to hypothyroidism will depend on the age of onset in childhood. Young children (1-3 years) can present with coarse facial features, hoarse cry and deceleration of linear growth, while onset later in childhood can be accompanied by features such as lethargy, constipation, growth retardation, muscular pseudohypertrophy, delayed or, rarely, precocious sexual development. Older children and adolescents may present with any of the following features: deterioration in academic 
performance, delayed skeletal maturation, delayed puberty and myxedematous appearance.

De Vries et al in their study investigated the clinical manifestations of autoimmune thyroiditis in 114 children, at the mean age 11.8 years. The most common reason for referral was goitre, in $39 \%$ of patients; and the actual prevalence on examination was almost twofold higher (77\%). In almost one-third of patients, ATD was diagnosed in the absence of clinical symptoms, either incidentally or on routine screening for high-risk groups [11]. The patients considered to be at high risk showed no significant differences in anthropometric, clinical or laboratory data compared to the patients referred for goitre. Also the same was the prevalence of overt hypothyroidism in this group as in patients referred for goitre or clinical symptoms of hypothyroidism, concluding that periodic thyroid function tests may be indicated in people at high risk of ATD.

It should be remembered that the underlying autoimmunity may predispose involvement of multiple organs and endocrine glands.

Hashimoto thyroiditis may be the initial presentation of an autoimmune polyglandular syndrome. It also can be associated with other coexisting autoimmune diseases such as diabetes mellitus type 1 , celiac disease, Addison's disease, pernicious anemia.

Kordonouri et al. in a multicenter survey investigated the thyroid autoimmunity in a very large nationwide cohort of 17,749 patients with type 1 diabetes aged $0.1-20$ years that were treated in 118 pediatric diabetes centers in Germany and Austria. Significantly elevated titers of at least one thyroid antibody were found in 1,530 patients (21.6\%) supporting previous findings from smaller cohorts of a high prevalence of thyroid autoimmunity in children and adolescents with type 1 diabetes [54]. In other study in Caucasian populations with diabetes in the U.S., thyroid autoimmunity prevalence of even $50 \%$ has been reported [55].

All these data support the recommendation for regular, i.e., yearly, examinations of thyroid antibodies, in all children with type 1 diabetes starting from onset of diabetes or, at latest before puberty. In cases of positive antibodies, thyroid function tests and ultrasound assessment are recommended in order to minimize the risk of undiagnosed hypothyroidism in young patients.

Celiac disease (CD) has increasingly become considered as a multi-organ disorder and has been linked to a number of diseases including autoimmune disorders. Several studies have shown a positive association of celiac disease with increased prevalence of autoimmune thyroid antibodies. In prospective studies of adults with CD, autoimmune thyroid disease was observed in $14 \%$ and $30.3 \%$ of patients. Ansaldi et al provided a multicenter study that included 343 biopsy proven CD patients, aged 9 months to 18 years. Autoimmune thyroid disease was found in 90 (26.2\%) of the CD patients, even those on a gluten free diet. This high prevalence points the importance of thyroid status assessment at diagnosis and at follow up evaluation in children with CD [56]. Meloni at al. in their study reported $10.5 \%$ prevalence of autoimmune thyroiditis in 324 children with proven celiac disease in Sardinia, Italy [57].

The coexistence of papillary thyroid carcinoma and $\mathrm{HT}$ is reported to range from $10 \%$ to $58 \%$ in various studies [58]. The prevalence of HT in patients with papillary thyroid carcinoma has been reported to be significantly higher compared to the prevalence of benign thyroid tumours. Patients with HT are suggested to be at higher risk for papillary thyroid carcinoma compared with patients without HT [59].

Hashimoto's encephalopathy (HE) is an underrecognized cause of acute encephalopathy both in children and adults. It is always associated with elevated levels of antithyroid antibodies and sometimes associated with chronic lymphocytic thyroiditis and goiter [60]. Adequate information is not available about the frequency of Hashimoto's encephalopathy in children. The prevalence in adult patients is estimated to be 2.1 / 100,000 [61].

The clinical picture of a relapsing and remitting encephalopathy characterized by seizures, stroke-like episodes, neurological signs such as myoclonus and tremor, cognitive disturbance and hallucinations, and other psychotic symptoms is highly suggestive of Hashimoto's encephalopathy [62].

Normal routine investigations, nonspecific neuroimaging and CSF findings (apart from elevated protein), and encephalopathic EEG can be supportive of the diagnosis. Thyroid hormone studies are not helpful, but may identify subclinical thyroid dysfunction [62]. Detection of antithyroid (in particular anti-TPO) antibodies confirms the diagnosis. As anti-TPO antibodies are detected in as many as $10 \%$ of the general population, high titers (usually over 100-fold normal) [63] of these antibodies in conjunction with the clinical features of Hashimoto's encephalopathy are necessary before a 
diagnosis can be made. Corticosteroid responsiveness can also support the diagnosis.

\section{Diagnosis}

Thyroid function is estimated by measuring $\mathrm{FT} 4$ and TSH. Euthyroid AT is diagnosed if both FT4 and TSH are normal. The typical patient with hypothyroidism secondary to AT will have an elevated TSH ("typically" over $10 \mathrm{IU} / \mathrm{mL}$ ), a low FT4, and positive titer of anti-TPO antibodies. Subclinical hypothyroidism is defined as TSH elevation with normal concentrations of circulating thyroid hormones (FT4 and FT3).

Majority of these patients are asymptomatic, but many studies suggest that individuals with the combined risk factors of TSH level above the normal limit and positive thyroid antibodies (anti-TG or anti-TPO) are at high risk for progression to overt hypothyroidism. Therefore, thyroid hormone replacement treatment is recommended in all patients with TSHvalues $>10 \mathrm{IU} / \mathrm{mL}$ or with $\mathrm{TSH}$ values $>5 \mathrm{IU} / \mathrm{mL}$ in combination with goiter and thyroid autoantibodies [64]. Anti-TPO antibodies are the most sensitive screening for AT. Little further benefit is gained by the additional measurement of antiTG antibodies, although they may be added if anti-TPO titers are negative [64].

Hashimoto's thyroiditis is diagnosed based on findings of seropositivity for $\mathrm{Tg}$ autoantibodies and/or TPO autoantibodies, accompanied by at least one of the following: abnormal thyroid function; enlarged thyroid gland; morphological changes on thyroid ultrasound; cytomorphological features of chronic lymphocytic thyroiditis on fine needle aspiration. Fine needle aspiration that was more frequently performed in the past is not necessary for the diagnosis, although it might be helpful in cases with nodules, or unusual finding on ultrasound.

Ultrasonography (USG) is a proved useful tool in the evaluation of thyroid diseases. Reduced echogenicity on USG is considered to be characteristic of AT. The degree of hypoechogenicity was not only found to have a significant correlation with the levels of circulating thyroid antibodies and thyroid dysfunction, but was also shown to predict the evolution towards hypothyroidism in euthyroid subjects $[65,66]$.

\section{Therapy}

Children with hypothyroidism should be treated with levothyroxine replacement therapy. Thyroid hormone replacement has been used for more than 100 years in the treatment of hypothyroidism, and there is no doubt about its overall efficacy. A starting dose can be estimated based upon the patient's age and body weigh. Levothyroxine has good intestinal absorption and its long halflife of $5-7$ days allow oral administration once a day. Levothyroxine should be administered at least 20 min, before eating or ingestion of any medication known to impair its absorption, such as calcium and iron supplements, sucralfate, potassium-binding resins, antacids containing aluminium, and bile-acids binding resins. All other medications should be checked for interactions, particularly with antidepressants and seizure medications.

Although very rare, the development of pseudotumor cerebri associated with the initiation of levothyroxine has been described in a small number of school-age children [67].

Also long-standing untreated hypothyroidism might cause hyperplasia of the pituitary thyrotrophs mimicking pituitary macroadenoma. Kocova et al. reported 11-year old girl with long-standing acquired primary hypothyroidism leading to pituitary pseudotumor that improved rapidly after the introduction of therapy with L-thyroxine. Review of the few other described cases in the literature led to conclusion that the possibility of pituitary hyperplasia due to primary hypothyroidism should be taken into consideration whenever an enlarged homogeneous pituitary gland in children is detected [68].

There is considerable debate regarding the management of children with euthyroidism or subclinical hypothyroidism. At the same time, studies have shown that treating subclinical hypothyroidism may confer benefits, such as delay of progression to overt hypothyroidism [69], reduction of the thyroid size [70], improvement of the lipid profile [71], and correction of growth velocity [72].

Svensson et al. in their study investigated the effect of levothyroxine treatment on thyroid size in 90 children with autoimmune thyroiditis. Their results showed that levothyroxine treatment is effective in reducing thyroid volume in pediatric patients and is suggested in treatment of goiter caused by autoimmune thyroiditis especially in cases of hypothyroid, but also in euthyroid children [7]. Consensus statement on subclinical thyroid dysfunction has recommended LT4 therapy for adults with subclinical hypothyroidism, in whom serum TSH levels are greater than $10 \mathrm{mIU} / \mathrm{L}$ [73]. Since no such consensus exists regarding children with subclinical hypothyroidism, clinical judgment is advised taking into 
consideration the need for constant monitoring of therapy and ensuring compliance with therapy.

The natural history of HT in children and adolescents is not fully known. Few studies have examined the spontaneous evolution of the disease [9]. A recent Italian retrospective study described the outcome of 160 children affected with HT followed for up to 32.6 years in 20 paediatric endocrine clinics [74]. At 5 years of follow-up, more than $50 \%$ of the patients remained or became euthyroid.The authors analyzed reliable prognostic factors to predict disease evolution. However, there were no differences regarding clinical measures, thyroid volume, and antibody concentrations in the group with normal TSH levels and the group with elevated TSH levels.

Parents of children with AT should be advised that the hypothyroidism is likely to be permanent and monitoring of thyroid function for all patients should be lifelong. The prognosis for recovering lost linear growth depends on the duration of the hypothyroidism as well as the age when the treatment was initiated.

Some authors offer a trial off L-T4 therapy to adolescents, after the completion of growth and puberty. Thyroid function is retested 6-8 weeks after the discontinuation of medication, to determine if hypothyroidism is permanent and potentially restart therapy [64].

\section{Acknowledgements}

Publication fee for this review article was covered by Ss Cyril and Methodius University Skopje PhD School.

\section{References}

1. Rivkees SA, Bode HH, Crawford JD. Long-term growth in juvenile acquired hypothyroidism: the failure to achieve normal adult stature. N Engl J Med. 1988;318:599-602.

2. Kiess W, Galler A, Reich A, et al. Clinical aspects of obesity in childhood and adolescence. Obes Rev. 2001;2:29-36.

3. Ryan GL, Feng X, Brasil d'Alva C, et al. Evaluating the roles of follicle-stimulating hormone receptor polymorphisms in gonadal hyperstimulation associated with severe juvenile primary hypothyroidism. J Clin Endocrinol Metab. 2007;92:2312-17.

4. Vanderpump MPJ, Tunbridge WMG, French JM, Appleton $D$, Bates D, Clark F, et al. The incidence of thyroid disorders in the community: a twenty year follow-up of the Wickham survey. Clin Endocrinol. 1995;43:55-68

5. Zois C, Stavrou I, Kalogera C, Svarna E. High prevalence of autoimmune thyroiditis in school children after elimination of iodine deficiency in northwestern Greece. Thyroid. 2003; 13:485-9.

6. Inoue M, Taketani N, Sato T, Nakajima H. High incidence of chronic lymphocytic thyroiditis in apparently healthy school children: epidemiological and clinical study. Endocrinol Jpn. 1975; 22:483-8.

7. Svensson J, Ericsson UB, Nilsson P, Olsson C, Jonsson B, Lindberg $B$, Ivarsson SA. Levothyroxine treatment reduces thyroid size in children and adolescents with chronic autoimmune thyroiditis. J Clin Endocrinol Metab. 2006; 91(5):1729-34

8. Demirbilek H, Kandemir N, Gonc EN, Ozon A et al. Hashimoto's thyroiditis in children and adolescents: a retrospective study on clinical, epidemiological and laboratory properties of the disease. J Pediatr Endocrinol Metab. 2007;20: 1199-1205.

9. Gopalakrishnan S, Chugh PK, Chhillar M, Ambardar VK, Sahoo M, Sankar R, Goitrous autoimmune thyroiditis in a pediatric population: a longitudinal study. Pediatrics. 2008;122: e670-674.

10. Corrias A, Cassio A, Weber G, et al.Thyroid nodules and cancer in children and adolescents affected by autoimmune thyroiditis. Arch Pediatr Adolesc Med. 2008;162:526-531.

11. de Vries L, Bulvik S, Phillip M. Chronic autoimmune thyroiditis in children and adolescents: at presentation and during long-term follow-up. Arch Dis Child. 2009;94: 33-37.

12. Skarpa V, Êousta E, Tertipi A, et al. Epidemiological characteristics of children with autoimmune thyroid disease. Hormones (Athens). 2011;10(3):207-214.

13. Ostergaard GZ, Jacobsen BB.,Atrophic, autoimmune thyroiditis in infancy. A case report. Horm Res. 1989;31:190192.

14. Saenger P. Turner syndrome; in Sperling MA(ed): Pediatric Endocrinology, ed 3. Philadelphia, Saunders Elsevier, 2008, pp 610-661.

15. El-Mansoury M, Bryman I, Berntorp K, Hanson C, Wilhelmsen L, Landin-Wilhelmsen K. Hypothyroidism is common in Turner syndrome: results of a five-year follow up. J Clin Endocrinol Metab. 2005; 90: 2131-2135.

16. Mortensen KH, Cleemann L, Hjerrild BE, Nexo E, Locht H, Jeppesen EM, Gravholt $\mathrm{CH}$. Increased prevalence of autoimmunity in Turner syndrome - influence of age. Clin Experim Immunol. 2009; 156:205-210.

17. Kocova M, Sukarova-Angelovska E, Spasevska S. Thyroid function in obese children. Horm Res. 2009;72 Suppl.3: 286. 
18. Weetman AP. Autoimmune thyroid disease: propagation and progression. Eur J Endocrinol. 2003;148:1-9.

19. Weetman AP: New aspects of thyroid autoimmunity. Horm Res. 1997;48(suppl 4):51-5.

20. Harvald B, Hauge M. Catamnestic investigation of Danish twins; a preliminary report. Dan Med Bull. 1956;3:150-8.

21. Villanueva R, Greenberg DA, Davies TF, Tomer Y. Sibling recurrence risk in autoimmune thyroid disease. Thyroid. 2003; 13:761-764.

22. Yaron $\mathrm{T}, \mathrm{Amanda} \mathrm{H}$. The etiology of autoimmune thyroid disease: A story of genes and environment. Journal of Autoimmunity. 2009; 32: 231-239.

23. Tandon N, Zhang L, Weetman AP. HLA associations with Hashimoto's thyroiditis. Clin Endocrinol. 1991;34:383-386.

24. Zantut-Wittmann DE, Persoli L, Tambascia MA, Fischer E, Franco Maldonado D, Costa AM, et al. HLA-DRB1*04 and HLADQB1*03 association with the atrophic but not with the goitrous form of chronic autoimmune thyroiditis in a Brazilian population. Horm Metab Res. 2004;36:492-500.

25. Jenkins D, Penny MA, Fletcher JA, Jacobs KH, Mijovic $\mathrm{CH}$, Franklyn JA, et al. HLA class II gene polymorphism contributes little to Hashimoto's thyroiditis. Clin Endocrinol. 1992; 37:141-145.

26. Zeitlin AA, Heward JM, Newby PR et al. Analysis of HLA class II genes in Hashimoto's thyroiditis reveals differences compared to Graves' disease. Genes Immun. 2008;9:358-363.

27. Tomer Y, Concepcion E, Greenberg DA. A C/T singlenucleotide polymorphism in the region of the CD40 gene is associated with Graves disease. Thyroid. 2002;12:1129-1135.

28. Park JH, Chang HS, Park CS, Jang AS, Park BL, Rhim TY, Uh ST, Kim YH, Chung IY, Shin HD. Association analysis of CD40 polymorphisms with asthma and the level of serum total IgE. Am J Respir Crit Care Med. 2007;175:775-782.

29. Raychaudhuri S, Remmers EF, Lee AT, Hackett R, et al. Common variants at CD40 and other loci confer risk of rheumatoid arthritis. Nat Genet. 2008;40:1216-1223.

30. Gaffney PM, Langefeld CD, Graham RR, Ortmann WA, Williams AH, Rodine PR, Moser KL, Behrens TW. Finemapping chromosome 20 in 230 systemic lupus erythematosus sib pair and multiplex families: evidence forgenetic epistasis with chromosome 16q12. Am J Hum Genet. 2006;78:747-758.

31. Australia and New Zealand Multiple Sclerosis Genetics Consortium (ANZgene). Genome-wide association study identifies new multiple sclerosis susceptibility loci on chromosomes 12 and 20. Nat Genet. 2009; 41:824-828.

32. Jacobson EM, Tomer Y. The CD40, CTLA-4, thyroglobulin, TSH receptor, and PTPN22 gene quintet and its contribution to thyroid autoimmunity: back to the future. J Autoimmun. 2007;
28:85-98.

33. Velaga MR, Wilson V, Jennings CE et al. The codon 620 tryptophan allele of the lymphoid tyrosine phosphatase (LYP) gene is a major determinant of Graves' disease. J Clin Endocrinol Metab. 2004;89:5862-5865.

34. Criswell LA, Pfeiffer KA, Lum RF, et al. Analysis of families in the multiple autoimmune disease genetics consortium (MADEGC) collection: the PTPN22 620W allele associates with multiple autoimmune phenotypes. Am J Hum Genet. 2005; 76:561-571.

35. Ban Y, Tozaki T, Taniyama M, et al. The codon 620 single nucleotide polymorphism of the protein tyrosine phosphatase22 gene does not contribute to autoimmune thyroid disease susceptibility in the Japanese. Thyroid. 2005;15:1115-1118.

36. Ban Y, Tozaki T, Taniyama M, Nakano Y \& Hirano T. (2010). Association of the protein tyrosine phosphatase nonreceptor 22 haplotypes with autoimmune thyroid disease in the Japanese population. Thyroid. 2010;20(8):893-899.

37. Pedersen IB, Knudsen N, Jorgensen T, Perrild H, Ovesen L, Laurberg P. Thyroid peroxidase and thyroglobulin autoantibodies in a large survey of populations with mild and moderate iodine deficiency. Clin Endocrinol. 2003;58:36-42.

38. Pirro MT, De Filippis V, Di Cerbo A, Scillitani A, Liuzzi A, Tassi V. Thyroperoxidase microsatellite polymorphism in thyroid diseases. Thyroid. 1995;5:461-464.

39. Tomer Y, Greenberg DA, Concepcion E, et al. Thyroglobulin is a thyroid specific gene for the familial autoimmune thyroid diseases. J Clin Endocrinol Metab. 2002; 87:404-407.

40. Tomer Y, Ban Y, Conception E et al. Common and unique susceptibility loci in Graves and Hashimoto diseases: results of whole-genome screening in a data set of 102 multiplex families. Am J Hum Genet. 2003;73:736-747.

41. Ku CS, Loy EY, Pawitan Y, Chia KS. The pursuit of genomewide association studies: where are we now? J Hum Genet. 2010;55:195-206.

42. Tomer Y. Genetic susceptibility to autoimmune thyroid disease: past, present, and future. Thyroid. 2010; 20:715-725.

43. Papanastasiou L, Vatalas L, Koutras DA, Mastorakos G. Thyroid autoimmunity in the current iodine environment. Thyroid. 2007;17:729-739.

44. Teng W, Shan Z, Teng X, Guan H, et al. Effect of iodine intake on thyroid diseases in China. N Engl J Med. 2006;354: 2783-2793.

45. Derumeaux E, Valeix P, Castetbon K, Bensimon M, Boutron-Ruault MC, Arnaud JH, Hercberg S. Association of selenium with thyroid volume and echostructure in 35- to 60year-old French adults. Eur J Endocrinol. 2003;148: 309-315.

46. Duntas LH, Mantzou E, Koutras DA. Effects of a six month 
treatment with elenomethionine in patients with autoimmune thyroiditis. Eur J Endocrinol. 2003;148: 389-393.

47. Tomer $Y$, Villanueva R. Hepatitis C and thyroid autoimmunity: is there a link? Am J Med. 2004;117: 60-61.

48. Brent GA. Environmental exposures and autoimmune thyroid disease. Thyroid. 2010;20; 755-761.

49. Male DK, Champion BR, Pryce G, Matthews H, Shepherd P. Antigenic determinans of human thyreoglobulin differentiated using antigen fragments. Immunology. 1985;54:419-427.

50. Tomer Y. Anti-thyroglobulin autoantibodies in autoimmune thyroid diseases: cross-reactive or pathogenic? Clin Immunol Immunopathol. 1997;82:3-11.

51. Chardes T, Chapal N, Bresson D, Bes C, Giudicelli V, Lefranc MP, Peraldi-Roux S. The human anti-thyroid peroxidase autoantibody repertoire in Graves' and Hashimoto's autoimmune thyroid diseases. Immunogenetics. 2002;54:141157.

52. Dayan CM, Daniels GH. Chronic autoimmune thyroiditis. New Eng J Med.1996;335: 99-107.

53. Kliegman RM. Disorder of thyroid gland. In: Kliegman RM, Behrman RH, Jenson HB, Stanton BMD (eds). Nelson Textbook of Pediatrics. 18th ed, Sounders, 2007.

54. Kordonouri O, Klinghammer A, Lang EB, Grüters-Kieslich A, Grabert M, Holl RW. Thyroid autoimmunity in children and adolescents with type 1 diabetes: a multicenter survey. Diabetes Care. 2002;25(8):1346-50.

55. Burek CL, Rose NR, Guire KE, Hoffmann WH. Thyroid autoantibodies in black and white children and adolescents with type 1 diabetes mellitus and their first-degree relatives. Autoimmunity. 1990;7:157-167.

56. Ansaldi N, Palmas T, Corrias A, Barbato M, D'Altiglia MR, Campanozzi A, Baldassarre M, Rea F, Pluvio R, Bonamico M, Lazzari R, Corrao G. Autoimmune Thyroid Disease and Celiac Disease in Children. J Pediatr Gastroenterol Nutr. 2003;37(1):63-6.

57. Meloni A, Mandas C, Jores RD, Congia M. Prevalence of autoimmune thyroiditis in children with celiac disease and effect of gluten withdrawal. J Pediatr. 2009 ;155(1):51-55.

58. Tamimi DM. The association between chronic lymphocytic thyroiditis and thyroid tumors. Int J Surg Pathol. 2002;10: 141146.

59. Holm LE, Blomgren $\mathrm{H}$, Lowhagen T. Cancer risks in patients with chronic lymphocytic thyroiditis. N Engl J Med. 1985; 312: 601-604.

60. Gayatri NA, Whitehouse WP. Pilot survey of Hashimoto's encephalopathy in children. Dev Med Child Neurol. 2005;47: 556-558.
61. Ferraci F, Bertiago G, Moretto G. Hashimoto encephalopathy: epidemiologic data and pathogenetic considerations. J Neurol Sci. 2004;217:165-168.

62. Mocellin R, Walterfang M, Velakoulis D. Hashimoto's Encephalopathy Epidemiology, Pathogenesis and Management. CNS Drugs. 2007;21:799-811.

63. Kothbauer-Margreiter I, Sturzenegger M, Komor J, Baumgartner R, Hess CW. Encephalopathy associated with Hashimoto thyroiditis. J Neurol. 1996;243: 585-593.

64. Cappa M, Bizzarri C, Crea F. Autoimmune thyroid diseases in children. J Thyroid Res. 2010;2011:675703.

65. Marcocci C, Vitti P, Cetani F, Catalano F, Concetti R, Pinchera A. Thyroid ultrasonography helps to identify patients with diffuse lymphocytic thyroiditis who are prone to develop hypothyroidism. J Clin Endocrinol Metab. 1991;72:209-213.

66. Pedersen OM, Aardal NP, Larssen TB, Varhaug JE, Myking $\mathrm{O}$, Vik-Mo $\mathrm{H}$. The value of ultrasonography in predicting autoimmune thyroid disease. Thyroid. 2000;10:251-259.

67. Van Dop C, Conte FA, Koch TK, Clark SJ, Wilson-Davis SL, Grumbach MM. Pseudotumor cerebri associated with initiation of levothyroxine therapy for juvenile hypothyroidism. New Engl J Med. 1983;308: 1076-1080.

68. Kocova M, Netkov S, Sukarova-Angelovska E. Pituitary pseudotumor with unusual presentation reversed shortly after the introduction of thyroxine replacement therapy. J Pediatr Endocrinol Metab. 2001;14(9):1665-9.

69. Padberg S, Heller K, Usadel KH, et al. One-year prophylactic treatment of euthyroid Hashimoto's thyroiditis patients with levothyroxine: is there a benefit? Thyroid. 2001;11:249-55.

70. Radetti G, Gottardi E, Bona G, et al. Study Group for Thyroid Disease of the Italian Society for Pediatric Endocrinology and Diabetes. The natural history of euthyroid Hashimoto's thyroditis in children. J Pediatr. 2006;149:827-32.

71. Monzani F, Caraccio N, Siciliano G, et al. Clinical and biochemical features of muscle dysfunction in subclinical hypothyroidism. J Clin Endocrinol Metab. 1997;82:3315-18.

72. Cetinkaya E, Aslan A, Vidinlisan S, et al. Height improvement by L-thyroxine treatment in subclinical hypothyroidism. Pediatr Int. 2003;45:534-7.

73. Surks MI, Ortiz E, Daniels GH, Sawin CT, Col NF, Cobin $\mathrm{RH}$, Franklyn JA, Hershman JM, Burman KD, Denke MA, Gorman C, Cooper RS, Weismann NJ. Subclinical thyroid disease. Scientific review and guidelines for diagnosis and management. J Am Med Assoc. 2004;291:228-338.

74. Radetti G, Gottardi E, Bona G, Corrias A, Salardi S, Loche $\mathrm{S}$. The natural history of euthyroid Hashimoto's thyroiditis in children. J Pediatrics. 2006;149: 827-832. 